\title{
Supplementation of in vitro maturation medium with serum from dairy cows at early and late lactation in the in vitro production of bovine embryos
}

\author{
[Suplementação no meio de maturação in vitro com soro de vacas no início e final da lactação \\ na produção in vitro de embriões bovinos]
}

\section{"Comunicação Breve/Short communication"}

\author{
Letícia Franco Collares $^{1}$, Jorgea Pradieé ${ }^{1 *}$, Morgana Alves Borges ${ }^{1}$, Bruna Mion ${ }^{1}$, \\ Patrícia Gindri ${ }^{1}$, Janaína Fadrique ${ }^{1}$, Joao Alveiro Alvarado Rincón ${ }^{1}$, \\ Lígia Margareth Cantarelli Pegoraro ${ }^{2}$, Augusto Schneider ${ }^{1}$, Marcio Nunes Corrêa ${ }^{1}$
}

\footnotetext{
${ }^{1}$ Programa de Pós-graduação em Veterinária, Faculdade de Veterinária, Universidade Federal de Pelotas, Pelotas-RS, Brasil.

${ }^{2}$ Empresa Brasileira de Pesquisa Agropecuária, Embrapa Clima Temperado, Pelotas-RS, Brasil.

*Autor para correspondência/Corresponding author: E-mail: jorgeapradiee@ hotmail.com
}

\begin{abstract}
The transition period of dairy cows is characterized by several metabolic alterations, due to the negative energy balance, which negatively affects fertility. The aim of this study was to evaluate the effect of supplementing the in vitro maturation medium with serum from dairy cows at early and late lactation in the oocyte maturation on the rates of nuclear maturation, cleavage and initial embryo development. The cumulus-oocyte complexes (COCs) were randomly divided into treatments: LL: serum from four cows at $354 \pm 3.8$ days in milk (DIM); and EL: serum from four cows at $10.8 \pm 4.8$ DIM. Subsequently, the COCs were submitted to maturation, fertilization; and in vitro culture in an incubator at $39^{\circ} \mathrm{C}$ with $5 \% \mathrm{CO}_{2}$. For analysis of nuclear maturation; oocytes were collected after IVM, denuded and stained with Hoechst ${ }^{\circledR}$. No difference was observed in the number of oocytes that reached metaphase II among treatments. The cleavage rate was not different between LL $(59.3 \% ; 320 / 540)$ and EL $(47.0 \% ; 243 / 517)$ treatments $(\mathrm{P}>0.05)$, as embryonic development between LL $(15.0 \% ; 81 / 540)$ and EL $(16.6 \% ; 86 / 517)(\mathrm{P}>0.05)$. It was concluded that supplementation with serum from cows at different lactation periods during the bovine oocyte IVM did not influence the results of in vitro embryo production.
\end{abstract}

Keywords: metabolism; oocyte maturation; transition period.

\section{Resumo}

O período de transição das vacas leiteiras é caracterizado por diversas alterações metabólicas, devido ao balanço energético negativo, que afeta negativamente a fertilidade. O objetivo deste estudo foi avaliar o efeito da suplementação no meio de maturação de oócitos in vitro, de soro de vacas leiteiras no início e no final da lactação, sobre as taxas de maturação nuclear, clivagem e desenvolvimento embrionário inicial. Os COCs foram divididos aleatoriamente nos tratamentos: LL: soro de quatro vacas a $354 \pm 3,8$ dias em lactação (DEL) e EL: soro de quatro vacas a 10,8 $\pm 4,8 \mathrm{DEL}$. Posteriormente, os COCs foram submetidos à maturação, fecundação e cultivo in vitro em incubadora a $39^{\circ} \mathrm{C}$ com $5 \%$ de CO2. Para análise da maturação nuclear, os oócitos foram coletados após MIV, desnudados e corados com Hoechst ${ }^{\circledR}$. Nenhuma diferença foi observada no número de oócitos que atingiram a metáfase II entre os tratamentos. A taxa de clivagem não foi diferente entre os tratamentos LL $(59,3 \%$; 320/540) e EL $(47,0 \% ; 243 / 517)(\mathrm{P}>0,05)$, assim como o desenvolvimento embrionário entre LL $(15,0 \% ; 81 / 540)$ e EL $(16,6 \% ; 86 / 517)(\mathrm{P}>0,05)$. Concluiu-se que a suplementação com soro de vacas em diferentes períodos de lactação durante a MIV de oócitos bovinos não influenciou os resultados da produção in vitro de embriões.

Palavras-chave: maturação oocitária; metabolismo; período de transição. 
The transition period in dairy cows encompasses the three weeks before calving extending up to three weeks postpartum (Mulligan and Doherty, 2008). This period is critical for highyielding dairy cows, since it requires several metabolic adjustments to support the transition from gestation to lactation (Mullins et al., 2012). The early lactation is characterized by an imbalance between food intake and the energy expenditure required for milk production, resulting in a high degree of lipolysis (Leroy et al., 2006) leading to a physiological status called negative energy balance (NEB) (Esposito et al., 2014).

During NEB, the intense mobilization of body reserves results in an increased serum concentration of non-esterified fatty acids (NEFA) and beta-hydroxybutyrate (BHBA) (Martinez et al., 2012). This mobilization of adipose and muscular tissue is accompanied by metabolic and hormonal alterations such as reduced serum levels of glucose, insulin and insulin-like growth factor I (IGF-I), resulting in an overall poor reproductive performance (O'Doherty et al., 2014). Therefore, biochemical changes during NEB are reflected in poor developmental competence of bovine oocytes (Leroy et al., 2008a). The elevated NEFA concentrations during oocyte maturation have a profound negative impact on embryo quality; effects which can persist up to seven days after removal of NEFA exposure, affecting blastocyst formation, viability, metabolism and gene transcription (Van Hoek et al., 2011). Oocytes and embryos are highly sensitive to the metabolic changes in their microenvironment, which could lead to a disturbed maturation, fertilization or early cleavage (Leroy et al., 2008b). The presence of NEFA during maturation delays the progression through meiosis, lowering fertilization, cleavage, and blastocyst development during in vitro culture under normal conditions (Jorritsma et al., 2004).

In view of these, the aim of this study was to evaluate the effect of supplementation of the in vitro maturation medium (IVM) with serum from dairy cows at early and late lactation during oocyte on the in vitro embryo production.

Blood samples were collected from eight Holstein dairy cows at different lactation stages, namely four cows at $10.8 \pm 4.8$ days in milk (DIM) and four at $354 \pm 3.8$ DIM. For the treatments, a pool of sera was prepared for both early (EL) and late lactation (LL). All serum was inactivated at $56^{\circ} \mathrm{C}$ for 30 minutes.
The in vitro production of bovine embryos was performed as described before (Rheingantz et al., 2006; Rincón et al., 2016). Thirteen replicates were performed with 1,057 cumulus-oocyte complexes (COCs). The selected COCs were randomly divided into treatments (serum from EL or LL cows), containing $50 \mathrm{COCs} /$ treatment in each replicate. In vitro maturation (IVM) was performed in TCM 199 medium, added with LH/FSH, pyruvate and antibiotics, enriched with $10 \%$ serum, from EL or LL cows, and incubated at $39^{\circ} \mathrm{C}$ with $5 \% \mathrm{CO}_{2}$ and $20 \% \mathrm{O}_{2}$ for 22 to 24 hours. After IVM, the oocytes were transferred to the in vitro fertilization (IVF) medium. For the insemination, the same Bos taurus taurus semen was used. The spermatic selection was performed with a mini Percoll gradient. The insemination was carried out with a concentration of $1 \times 10^{6}$ spermatozoa/mL, at the same atmospheric conditions as IVM for $20 \mathrm{~h}$.

The probable zygotes were washed three times and transferred to drops of SOFaa culture medium supplemented with 5\% serum and pyruvate at $39^{\circ} \mathrm{C}$ with $5 \% \mathrm{CO}_{2}$ and $20 \% \mathrm{O}_{2}$ for 7 days. The time of insemination was considered as day 0 , the cleavage rate was evaluated on day 3 (number of cleaved/number of inseminated), and finally, the rate of global embryonic development (blastocysts/number of inseminated) on day 7. On days 3 and 5, 30\% of culture medium was replaced.

For the evaluation of the nuclear maturation, four replicates were performed with a total of 213 oocytes. In order to evaluate the maturation, the oocytes were stained with Hoechst ${ }^{\circledR}$ for 10 min, fixed with Mowiol $^{\circledR}$ and evaluated under fluorescence microscopy according to the maturation stages: germ vesicle (GV), germinal vesicle first phase of meiosis (MI), anaphase, telophase and second phase of meiosis (MII). The oocytes were divided into two groups: mature and immature (Woudenberg et al., 2012).

Statistical analysis was performed using Statistix $10^{\circledR}$ software (2014). The analysis of serum biochemical parameters was performed through the Student's t-test and the analysis of cleavage. In addition, embryo development and nuclear maturation rates were performed using the ANOVA test, with Tukey post-hoc test $(\mathrm{P}<0.05)$.

Milk production and biochemical parameters evaluated in serum and inactivated serum pool from early lactation (EL) and late lactation (LL) cows is presented in Table 1. 
Paraoxonase 1 (PON1) activity was not detected in the pool of inactivated sera. Cholesterol levels were higher in the LL than in the EL group $(\mathrm{P}=0.02)$, and milk production was higher in $\mathrm{EL}$ than in the LL cows $(\mathrm{P}=0.03)$ (Table 1$)$. No other differences were detected among other metabolites evaluated.

Table 1. Milk production and biochemical parameters evaluated in serum and inactivated serum pool from early lactation (EL) and late lactation (LL).

\begin{tabular}{lccccc}
\hline \multicolumn{1}{c}{ Parameters } & EL $^{*}$ & Pool EL inactivated & LL $^{*}$ & Pool LL inactivated & P Value \\
\hline Milk production $(\mathrm{kg} / \mathrm{day})$ & $18.8 \pm 7.7^{\mathrm{b}}$ & - & $32.4 \pm 13.6^{\mathrm{a}}$ & - & 0.028 \\
Fat $(\%)$ & $3.3 \pm 0.3^{\mathrm{a}}$ & - & $2.8 \pm 0.5^{\mathrm{a}}$ & - & 0.817 \\
Protein $(\%)$ & $3.6 \pm 0.3^{\mathrm{a}}$ & - & $3.4 \pm 0.5^{\mathrm{a}}$ & - & 0.502 \\
SCC $(\mathrm{Cells} / \mathrm{mL})$ & $137.857^{\mathrm{a}}$ & - & $100.857^{\mathrm{a}}$ & - & 0.900 \\
Albumin $(\mathrm{mg} / \mathrm{dL})$ & $2.4 \pm 0.1^{\mathrm{a}}$ & 3.3 & $2.7 \pm 0.1^{\mathrm{a}}$ & 3.3 & 0.088 \\
Calcium $(\mathrm{mg} / \mathrm{dL})$ & $9.4 \pm 0.5^{\mathrm{a}}$ & 9.3 & $9.9 \pm 0.1^{\mathrm{a}}$ & 8.5 & 0.322 \\
Cholesterol $(\mathrm{mg} / \mathrm{dL})$ & $92.8 \pm 10.5^{\mathrm{b}}$ & 103 & $238.3 \pm 19.5^{\mathrm{a}}$ & 222 & 0.002 \\
Total protein $(\mathrm{g} / \mathrm{dL})$ & $8.2 \pm 0.3^{\mathrm{a}}$ & 8.8 & $8.7 \pm 0.3^{\mathrm{a}}$ & 8.9 & 0.312 \\
Triglycerides $(\mathrm{mg} / \mathrm{dL})$ & $12.5 \pm 3.1^{\mathrm{b}}$ & 13 & $71.5 \pm 29.9^{\mathrm{a}}$ & 16 & 0.143 \\
Urea $(\mathrm{mg} / \mathrm{dL})$ & $13.8 \pm 1.7^{\mathrm{a}}$ & 28 & $17.8 \pm 4.3^{\mathrm{a}}$ & 27 & 0.422 \\
PON1 activity $(\mathrm{U} / \mathrm{mL})$ & $81.5 \pm 11.4^{\mathrm{a}}$ & - & $110.2 \pm 13.3^{\mathrm{a}}$ & - & 0.154 \\
NEFA $(\mathrm{mmol} / \mathrm{L})$ & $0.3 \pm 0.0^{\mathrm{a}}$ & 0.5 & $0.3 \pm 0.0^{\mathrm{a}}$ & 0.5 & 0.154 \\
Haptoglobin $(\mathrm{g} / \mathrm{L})$ & - & 0.9 & - & 1.9 & - \\
BHBA $(\mathrm{mmol} / \mathrm{L})$ & - & 0.8 & - & 0.6 & - \\
Estradiol $(\mathrm{pg} / \mathrm{mL})$ & - & 20 & - & 20 & - \\
Progesterone $(\mathrm{pg} / \mathrm{mL})$ & - & 3.7 & - & 1.3 & - \\
\hline
\end{tabular}

*Data is presented as mean \pm standard error of the mean. Different letters on the same line mean statistical difference $(\mathrm{P}<0.05)$.

There was no difference $(\mathrm{P}=0.94)$ between the number of oocytes that reached the MII between treatments, being $76.8 \%(86 / 112)$ for LL and $82.2 \%$ (83/101) for EL.

The cleavage rate was not different between LL (59.3\%; 320/540) and EL (47\%; 243/517) $(\mathrm{P}>0.05)$. Embryo development was also not different between LL $(15 \% ; 81 / 540)$ and EL $(16.6 \%$; 86/517) ( $\mathrm{P}>0.05)$ (Figure 1). There was no difference in embryo development kinetics evaluated at D7 among EL and LL treatments.
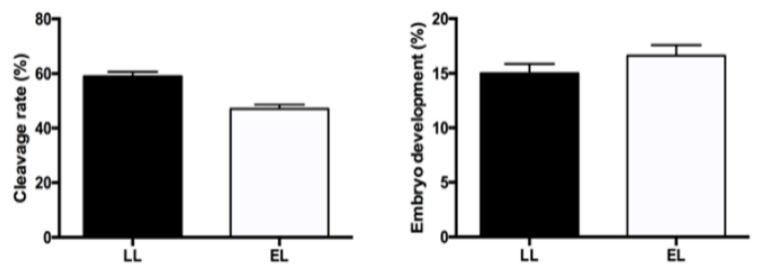

Figure 1. Cleavage and embryo development rates (\%) for late lactation (LL) and early lactation (EL).

Serum concentrations of NEFA (average 0.3 $\mathrm{mmol} / \mathrm{L}$ ) were similar for EL and LL cows, and this may explain the similarity in the results found for both cleavage and embryo development. This suggests that these cows did not undergo a severe NEB and, therefore, serum supplementation during IVM did not affect the evaluated parameters as we had hypothesized. However, other in vitro studies evaluating the presence of NEFA in the IVM medium observed delayed progression to oocyte meiosis, reduced cleavage, and blastocyst development (Jorritsma et al., 2004).

In addition, the presence of NEFA in the follicular fluid affects steroidogenesis, as well as oocyte developmental ability (Van Hoeck et al., 2011). Concentrations of NEFA in the media of the previous works were higher than those observed in the current study. In our work, we added cow sera at the beginning (EL) and at the end of lactation (LL), in order to obtain similar conditions that oocytes undergo in the beginning and at the end of lactation. However, when we used serum in the maturation medium, we added other factors than just NEFA, that we did not control, which may have influenced our results of nuclear maturation and embryo production. Although not conclusive, our data suggests that in the absence of an NEFA elevation in serum from EL cows, this serum is not detrimental for oocyte maturation.

Although cholesterol and triglycerides levels found in sera from EL were lower than that found in LL, no influence was observed on nuclear maturation, cleavage and embryonic development. HDL is the main lipoprotein in the ovarian follicular fluid that supplies cholesterol for steroidogenesis (Jaspard et al., 1996). Higher concentration of HDL-P in vitro was associated with a decrease in cleavage rate and embryo 
development on D7 (Rincón et al., 2018), which is in contrast with current findings. So, more data is still needed to clarify the mechanisms and roles of HDL on fertility.

Regarding milk production, although it was statistically different between EL and LL cow groups, due to the period of lactation, it also did not influence embryo development. Milk production is associated with negative effects on reproduction, but it is dependent on metabolic changes to affect reproduction. Previous studies have demonstrated associations between changes in milk production, subclinical ketosis, risks of diseases, and reproductive performance (Raboisson et al. 2014). However, each study reported the relevant risks using different thresholds for $\beta$-hydroxybutyrate and NEFA values. Moreover, changing the thresholds values can lead to different results and association to diseases and reproductive performance (Raboisson et al. 2014). Therefore, it is difficult to establish a universal cutoff value for these parameters and its negative effects on cow performance. The effect of milk yield on reproductive performance was weak and varied according to the level of milk yield of the herd (Rearte et al, 2018), further suggesting the metabolic adaptations to milk production are more important than milk yield per se.

Supplementation of the IVM media with serum from dairy cows at early and late lactation, in the absence of postpartum NEFA elevation, did not affect the rate of nuclear maturation, cleavage and embryo development.

\section{Conflict of interest}

The authors declare that do not have any conflict of interest.

\section{Ethics Committee}

The committee on ethics and biosafety approved this study considering the methods compatible with the ethical principles in animal experimentation (23110/005315-2009-48).

\section{Acknowledgments}

We thank the scholarship and funding provided by $\mathrm{CNPq}$ (Letícia Franco Collares, Morgana Alves Borges and Janaína Fadrique). CAPES (Jorgea Pradieé, Bruna Mion, Joao Alveiro Alvarado Rincón), and Famile slaughterhouse (Pelotas, RS) for providing ovaries, and ProgenAlta Genetics for providing semen for this study.

\section{References}

Esposito, G.; Irons, P.C.; Webb, E.C.; Chapwanya, A. Interactions between negative energy balance, metabolic diseases, uterine health and immune response in transition dairy cows. Animal Reproduction Science, 144(3-4):6071, 2014.

Jaspard, B.; Collet, X.; Barbaras, R.; Manent, J.; Vieu, C.; Parinaud, J.;[ Perret, B. Biochemical characterization of pre-beta 1 high- density lipoprotein from human ovarian follicular fluid: evidence for the presence of a lipid core. Biochemistry, 35:1352-1357, 1996.

Jorritsma, R.; César, M.L.; Hermans, J.T.; Kruitwagen, C.L.; Vos, P.L.; Kruip, T.A. Effects of non-esterified fatty acids on bovine granulosa cells and developmental potential of oocytes in vitro. Animal Reproduction Science, 81(3-4):225-35, 2004.

Leroy, J.L.; Van Soom, A.; Opsomer, G.; Bols, P.E. The consequences of metabolic changes in high-yielding dairy cows on oocyte and embryo quality. Animal, 2(8):1120-7, 2008 (a).

Leroy, J.L.; Van Soom, A.; Opsomer, G.; Goovaerts, I.G.; Bols, P.E. Reduced fertility in high-yielding dairy cows: are the oocyte and embryo in danger? Part II. Mechanisms linking nutrition and reduced oocyte and embryo quality in high-yielding dairy cows. Reproduction in domestic animals, 43(5):623-32, 2008 (b).

Leroy, J.L.; Vanholder, T.; Opsomer, G.; Van Soom, A.; de Kruif, A. The in vitro development of bovine oocytes after maturation in glucose and beta-hydroxybutyrate concentrations associated with negative energy balance in dairy cows. Reproduction in domestic animals, 41(2):119-23, 2006.

Martinez, N.; Risco, C.A.; Lima, F.S.; Bisinotto, R.S.; Greco, L.F.; Ribeiro, E.S.; Maunsell, F.; Galvão K.; Santos, J.E.P. Evaluation of peripartal calcium status, energetic profile, and neutrophil function in dairy cows at low or high risk of developing uterine disease. Journal of Dairy Science, 95:7158-7172, 2012.

Mulligan, F.J,. Doherty, M.L. Production diseases of the transition cow. Veterinary Journal, 176(1):3-9, 2008.

Mullins, C.R.; Mamedova, L.K.; Brouk, M.J., Moore, C.E.; Green, H.B.; Perfield, K.L.; Smith, J.F.; Harner, J.P.; Bradford, B.J. Effects of monensin on metabolic parameters, feeding behavior, and productivity of transition dairy cows. Journal of Dairy Science, 95(3):1323$36,2012$. 
O'Doherty, A.M.; O'Gorman, A.; al Naib, A.; Brennan, L.; Daly, E.; Duffy, P.; Fair, T. Negative energy balance affects imprint stability in oocytes recovered from postpartum dairy cows. Genomics, 104(3):177-85, 2014.

Rearte, R.; LeBlanc, S. J.; Corva, S. G.; de la Sota, R. L.; Lacau-Mengido, I. M.; Giuliodori, M. J. Effect of milk production on reproductive performance in dairy herds. Journal of Dairy Science, 101:1-10, 2018.

Rheingantz, M.G.T.; Pegoraro, L.M.C.; Dellagostin, O.A.; Pimentel, A.M.; Bernardi, M.L.; Deschamps, J.C. The sex ratio of in vitro produced bovine embryos is affected by the method of sperm preparation. Animal Reproduction, 3(4):423-430, 2006.

Rincón, J.; Madeira, E.M.; Campos, F.T.; Mion, B.; Silva, J.F.; Absalón-Medina, V.A.; Butler, W.R.; Corrêa, M.N.; Pegoraro, L.; Schneider, A. Exogenous paraoxonase-1 during oocyte maturation improves bovine embryo development in vitro. Reproduction in domestic animals, 51(5):827-30, 2016.

Rincón J.A.A.; Pradieé J.; Remião M.H; Collares T.V.; Mion,B.; Gasperin, B.G.; Rovani, M.T;
Corrêa, M.N.; Pegoraro, L.M.C.; Schneider, A. Effect of high-density lipoprotein on oocyte maturation and bovine embryo development in vitro. Reproduction in domestic animal, 00:1-11, 2018.

Raboisson D, Mounié M, Maigné E.Diseases, reproductive performance, and changes in milk production associated with subclinical ketosis in dairy cows: a meta-analysis and review. Journal of Dairy Science 97(12):7547-63, 2014.

Van Hoeck, V.; Sturmey, R.G.; Bermejo-Alvarez, P.; Rizos, D.; Gutierrez-Adan, A.; Leese, H.J.; Bols, P.E.J.; Leroy, J.L.M.R. Elevated nonesterified fatty acid concentrations during bovine oocyte maturation compromise early embryo physiology. PloSOne, 6(8):23183, 2011.

Woudenberg, A.B.; Gröllers-Mulderij, M.; Snel, C.; Jeurissen, N.; Stierum, R.; Wolterbeek, A. The bovine oocyte in vitro maturation model: a potential tool for reproductive toxicology screening. Reproductive Toxicology, 34(2):251-60, 2012. 